\title{
TYPOLOGIA PRZEJAWIANIA SIEC ZASAD KOMUNIKACJI INTERPERSONALNEJ W POLSKIM, UKRAIŃSKIM, BRYTYJSKIM ORAZ AMERYKAŃSKIM ŚRODOWISKACH JEZZYKOWO-KULTUROWYCH
}

\author{
ANATOLIJ ZAHNITKO \\ Doniecki Uniwersytet Narodowy, Donieck — Ukraina \\ LUBOMIRA HNATIUK \\ Wyższa Szkoła Informatyki i Zarządzania w Przemyślu, Przemyśl — Polska \\ ТИПОЛОГІЯ ВИЯВІВ КОМУНІКАТИВНИХ МАКСИМ \\ МІЖПЕРСОНАЛЬНОГО СПІЛКУВАННЯ В ПОЛЬСЬКОМУ, \\ УКРАЇНСЬКОМУ, БРИТАНСЬКОМУ Й АМЕРИКАНСЬКОМУ \\ ЛІНГВОКУЛЬТУРНИХ СЕРЕДОВИЩАХ \\ АНАТОЛІЙ ЗАГНІТКО \\ Донецький національний університет, Донецьк - Україна \\ ЛЮБОМИРА ГНАТЮК \\ Вища школа інформатики та управління в Перемишлі, Перемишль - Польща \\ АНОТАЦІЯ. У статті комунікативні максими розглядаються як відносні, але не \\ як абсолютні правила. Іноді в повсякденному міжособистісному спілкуванні виникає \\ прагматичний парадокс - неузгодженість максим. У статті проводиться розмежування \\ між уживанням максим в умовах різних мовних культур.
}

\section{THE TYPOLOGY OF THE MANIFESTATION OF THE COMMUNICATIVE MAXIMS OF INTERPERSONAL COMMUNICATION IN POLISH, UKRAINIAN, BRITISH AND AMERICAN CULTURAL AND LANGUAGE ENVIRONMENT}

\author{
ANATOLIY ZAHNITKO \\ Donetsk National University, Donetsk — Ukraine \\ LYUBOMIRA HNATYUK
}

Higher School of Informatics and Management in Przemysl, Przemysl — Poland

ABSTRACT. The article deals with the communicative maxims. Maxims are observed up to a certain point, rather than as absolute rules. Therefore, a pragmatic paradox sometimes can arise through the non-agreement of maxims in the situations of everyday interpersonal interaction in the conditions of different language cultures.

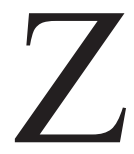

e względu na postępujące procesy globalizacyjne fundamentalne znaczenie dla efektywnej interakcji interpersonalnej ma prawidłowa komunikacja międzykulturowa. Dzisiejsze realia integracji oraz interferencji kultur różnych narodowości i państw dają interlokutorom coraz więcej okazji do poznawania zróżnicowanego kulturowego dyskursu. Wcześniej nie zwracano szczególnej uwagi na 
najważniejszy element komunikacji efektywnej - aktywne poszukiwanie najtrafniejszych, innymi słowy, najbardziej zrozumiałych sposobów wyrażania swych intencji i aktywne rozpoznawanie intencji zawartych w wypowiedziach rozmówcy, z równoczesnym śledzeniem wymogów sytuacji. Począwszy od lat siedemdziesiątych, okazało się, że studia nad językiem ograniczone do abstrakcyjnych analiz gramatycznych zdań i badania realności psychologicznej rozumienia i produkowania takich zdań nie dają pełnego wglądu w rzeczywiste posługiwanie się językiem w konkretnych sytuacjach mówienia. Nawiązując do idei komunikacji skutecznej, wybitny brytyjski lingwista G. Leech stwierdza: „Podczas konwersacji rozmówcy odczuwają nadrzędne pragnienie porozumienia się i starannie dopasowują swoje zachowania do wymogów sytuacji”'. Mówiąc inaczej, rozmówcy wykraczają poza dostarczane teksty, uwzględniając szerszy kontekst interpretacyjny. Niemal w każdej sytuacji komunikacyjnej działa zasada kontekstowej interpretacji wypowiadanych tekstów. Czasem wymaga to jedynie znajomości sytuacji, w której przebiega rozmowa, jednak innym razem zmusza do znacznego wysiłku intelektualnego, by właściwie uchwycić myśl rozmówcy.

Badanie w zaoferowanym wymiarze problemu jest przedsięwzięciem nowatorskim. $\mathrm{Z}$ jednej strony, naukowe podstawy badań mają oparcie $\mathrm{w}$ fundamentalnieteoretycznych zasadach oraz najnowszych osiagnięciach lingwistyki pragmatycznej, logiki, lingwistyki psychologicznej, kulturologii lingwistycznej itp. $\mathrm{Z}$ drugiej zaś strony, zaproponowana analiza opiera się na jakościowo nowych postulatach pragmatyki komunikacyjnej w zakresie własnych opracowań implikatur, presupozycji, postulatów, zasad i reguł komunikacji efektywnej. Owa oryginalność wkładu do dorobku dyscypliny naukowej w kraju i na świecie polega na zmianie orientacji społecznej w kierunku efektywnej komunikacji interpersonalnej i relacji komunikacyjno-pragmatycznych na poziomie dialogu międzykulturowego.

Obecnie pojęcie kompetencji komunikacyjnej i pragmatycznej odwołuje się do zasady dialogu kooperatywnego amerykańskiego badacza procesów komunikacyjnych, filozofa-logika Grice'a, który zasadę komunikacji skutecznej ujmuje w sposób następujący: "nadrzędną zasadą komunikacji efektywnej jest reguła kooperacji, zobowiązująca rozmówców do realizacji własnych wkładów $\mathrm{w}$ tworzenie wymiany w odpowiednim momencie przy jednoczesnej akceptacji celu i kierunku konwersacji"'.

Zasada kooperacji Grice'a opiera się na czterech regułach, tak zwanych maksymach, lub zasadach, których waga ujawnia się zwłaszcza wtedy, kiedy są łamane.

Reguła jakości: Realizować swój przekaz komunikacyjny zgodnie z prawda, a więc nie mówić tego, co jest fałszywe, do czego nie mamy przekonania lub co nie jest wystarczająco uzasadnione.

Reguła ilości: Realizować swój wkład tak, by był rozbudowany zgodnie z wymogami bieżących celów wymiany. Nie być bardziej szczegółowym, niż jest to wymagane.

Reguła relewancji, inaczej odpowiedniości: Mówić rzeczy związane z aktualnym przebiegiem rozmowy.

Reguła sposobu: Być zrozumianym przez rozmówcę, a to oznacza:

- Unikać wypowiedzi wieloznacznych.

- Mówić rzeczowo, krótko, bez przesadnego rozwijania tematów,

- Mówić w sposób uporządkowany, systematyczny.

${ }^{1}$ G. L e e ch, Principles of Pragmatics, London 1983, P. 6.

${ }^{2}$ H. Grice, Presupposition and Conversational Implicature, [in:] H. Grice, Radical Pragmatics, Ed. by P. Cole and J. Morgan, New York 1978, P. 2. 
Podsumowując, właściwy sposób pełnienia roli mówcy w świetle komunikacji efektywnej polega na tym, by mówić szczerze (zasada jakości), na temat (zasada odpowiedniości), jasno, rzeczowo (zasada sposobu) oraz przekazywać odpowiednią ilość informacji, nie za dużą, ale i nie za małą w stosunku do wymagań (zasada ilości).

Zasada uprzejmości jest kluczowa dla procesu komunikacyjnego. Wychodząc z założenia, iż komunikacja interpersonalna jest zjawiskiem społecznym (a nie tylko językowym), brytyjski lingwista G. Leech rozbudował i sprecyzował zagadnienie podejścia Grice'a do dialogu kooperatywnego, a także uzmysłowił, że zasady efektywnego dialogu interpersonalnego wymagaja, by znaczenia wypowiedzi były możliwe do zaakceptowania przez odbiorcę i formułowane w sposób niewywołujący nieprzyjemnych stanów uczuciowych. W związku z powyższym zaproponowane zostały następujące reguły uprzejmego kontaktu interpersonalnego ${ }^{3}$ :

Taktu: Wymaga unikania na ile jest to możliwe tematów nieprzyjemnych dla rozmówcy oraz otwartych uwag krytycznych.

Sympatii i aprobaty: Wymaga, by uczestnicy dialogu interpersonalnego wyrażali wzajemną życzliwość i akceptację zarówno swoich wypowiedzi, jak również zadowolenie z przebiegu rozmowy.

Skromności: Wymaga unikania otwartego wskazywania na swoje silne strony, sukcesy, chwalenia siebie w taki sposób, by mogło to wywołać poczucie niższości u odbiorcy.

Zgodności: Wymaga wyrażenia aprobaty dla stanowiska partnera, zgody na zawarte w jego wypowiedziach opinie konsekwentnie, kiedy tylko jest to możliwe. Odmowa jest łamaniem tej zasady i wymaga usprawiedliwienia.

Współdziałania: Wymaga wyrażenia dobrej woli kontynuowania konwersacji i poszukiwania najwłaściwszych sposobów organizacji swego wkładu w tę konwersację, podobnie jak w maksymach kooperacji Grice'a.

Reguła Polyanny: Wymaga, by unikać — jeśli tylko jest to możliwe podejmowania tematów przykrych dla rozmówcy, takich, które mogą spowodować u niego nieprzyjemne skojarzenia i smutek, konstruując wypowiedzi pośrednie.

Spośród wszystkich tych reguł najważniejsza wydaje się być zasada współdziałania, gdyż determinuje ona istnienie porozumiewania się oraz warunkuje wszystkie inne zasady komunikacji efektywnej.

Analiza porównawcza na materiale modeli komunikacyjnych $\mathrm{w}$ różnych środowiskach językowo-kulturowych pozwala dostrzegać cechy wspólne, jak również przewagę pewnych cech komunikacyjnych w jednym środowisku językowym, a w innej kulturze ich brak. Aktualność badanego zagadnienia językowokulturowego nie w sposób zaprzeczyć, ponieważ różnice społeczne i kulturowe często mają decydujący wpływ na przebieg procesu komunikacyjnego. Praktyczne zastosowanie wyników zaproponowanego badania nie budzi cienia wątpliwości, bowiem nieznajomość pewnych konwencjonalnych zachowań międzykulturowych może doprowadzić do różnego rodzaju kryzysów interpersonalnych, między innymi, do zaburzenia komunikacji między nadawcą i odbiorca.

Kulture polską cechuje ogromne znaczenie relacji rodzinnych, co ma swoje odzwierciedlenie, między innymi, w licznych nazwach związanych z określaniem stopnia pokrewieństwa. Podobnie dzieje się w kulturze ukraińskiej, która przypisuje relacjom rodzinnym dużą wartość: wciąż obecny jest model niedzielnych lub świątecznych spotkań w gronie rodziny i krewnych w celu dzielenia się swoimi radościami i smutkami.

\footnotetext{
${ }^{3}$ G. L e e ch, Principles of Pragmatics, London 1983, P. 131-139.
} 
Na tle kultury ukraińskiej kultura polska zdaje się mieć więcej cech kultury indywidualistycznej, w której mocno podkreśla się przynależność do swojego kraju, model: nasze polskie; jak również mocno podkreśla się prawa i potrzeby jednostki, nie zawsze skłonnej podporządkować się woli autorytetów, model: mi się należy.

Zarówno społeczeństwo brytyjskie jak polskie, i ukraińskie jest dużo bardziej zhierarchizowane, niż społeczeństwo amerykańskie. Ma to swoje odbicie w przywiązaniu dużej uwagi ku temu, jakie miejsce ktoś zajmuje w strukturze społecznej, w dużej ilości tytułów zawodowych w kulturach brytyjskiej i polskiej, a w ukraińskim środowisku językowym zwyczaj zwracania się po imieniu ojca. W polskim środowisku językowym nie używa się nazwiska jako dodatku uzupełniającego. Ma to swoją zaletę. Konieczność używania nazwiska powoduje po prostu konieczność jego znajomości oraz zapamiętania go. Czy w dzisiejszym zagonionym życiu zawsze warto tę dodatkowa informację przechowywać? Instytucjonalnie uwarunkowane formy zwrotu do odbiorcy można rozpatrywać jako kryterium stopnia formalizacji samej instytucji. W polskim środowisku kulturowym w celu realizowania zasady taktu „podnosi się" tytuły: z wice dyrektora do dyrektora, z kierownika działu do szefowej, $\mathrm{z}$ wice prezesa do prezesa; postępuje się również tak z tytułami akademickimi: „podnosi się np. DOKTORA do PROFESORA itd. zwykle z intencją pochlebstwa. Przy nierównym statusie rozmówców zgodnie $\mathrm{z}$ zasadami uprzejmości rezygnuje się z tytułu adresata „niższego" stopniem, np. PROFESOR w rozmowie z MAGISTREM daje znak przychylności opuszczając tytuł. W takim kontekście użycie tytułu może wyrażać dezaprobatę, krytykę, chęć przywołania do porządku itp.

$\mathrm{W}$ przeciwieństwie do polskiej tytułomanii i ukraińskiego zaformalizowanego zwyczaju tytułować wszystkich po imieniu oraz po imieniu ojca w kulturze amerykańskiej dystans pomiędzy interlokutorami jest o wiele mniejszy, nawiązuje się dużo więcej relacji bezpośrednich, rezygnując z używania stylu formalnego. $\mathrm{Z}$ drugiej strony, specyficznym jednak wydaje się być amerykański zwyczaj przedstawiania się rozmówcy, w telefonie i w rozmowie face to face: „Jestem pani Jonson”, „Jestem profesor Smith”, „Tu mówi mister Black!”. Zdaniem profesor Krystyny Pisarkowej : "Sygnalizowanie własnego nazwiska na pewno nie byłoby śmieszne, gdyby się przedstawiał Szekspir lub co najmniej Andy Warhol. Ale zobowiązanie odbiorcy do pamiętania, iż jakiś pan Przybijalski to pan Przybijalski, jest doprawdy wyrazem większej pychy Przybijalskiego niż wymaganie, aby wiedziano, iż należy on do klasy mecenasów, dyrektorów, kierowców, konduktorów itd."’4.

Charakterystyczne cechy konkretnej kultury językowej są jednym z podstawowych elementów, które wpaja się uczącym jakiegokolwiek języka obcego w celu zapobiegania szoku kulturowego. Próbując poznać inną kulturę, interlokutor intuicyjnie szuka odpowiedników w języku ojczystym, co w dużej mierze podpowiada, w jakich okolicznościach należy użyć te czy te wyrażenia. Należy jednak mieć świadomość, że nie zawsze spotkamy się z zupełną ekwiwalencją. Analizując różne środowiska językowe często będziemy mówić o pewnym podobieństwie, jednak czasami zakres użycia tych lub tych środków językowych będzie się różnił zupełnie. Mając na uwadze ten fakt, spróbujmy dokonać porównania pewnych zjawisk językowych, przedstawiając ich w odniesieniu do pewnych środowisk kulturowych.

W zależności od tego czy dane środowisko językowe preferuje szczerość i otwartość, a więc jest kulturą niskiego kontekstu; czy informacje są przekazywane w sposób pośredni na podstawie sugestii i domysłu w kulturach wysokiego kontekstu, jak w poniższym przykładzie:

${ }^{4} \mathrm{~K}$. P is a rkowa, Z pragmatycznej stylistyki, semantyki i historii języka. Wybór zagadnień, Kraków 1994, s. 11. 
(1) Hester: Mr. Arbuthnot is very charming.

Lady Caroline: Ah, yes! The young man who has a post in a bank. In my young days, Miss Worsley, one never met anyone in socjety who worked for living.

Hester: In America those are the people we respect most.

Lady Caroline: I have no doubt of it.

Hester: Mr. Arbuthnot has a beautiful nature! He is so simple, so sincere. He has one of the most beautiful natures I have ever come cross. It is a privilege to meet him.

Lady Caroline: It is not customary in England Miss Worsley, for a young lady to speak with such enthusiasm of any person of the opposite sex. English women conceal their feelings till after the are married. They show them then.

Hester: Do you, in England, allow no friendship to exist between a young man and a young girl?( Oscar Wilde. A Woman of No Importance).

Komunikacyjna reakcja Lady Caroline It is not customary in England Miss Worsley, for a young lady to speak with such enthusiasm of any person of the opposite sex. English women conceal their feelings, określa środowisko brytyjskie jako kulturę wysokiego kontekstu komunikacyjnego z cechami kultury indywidualistycznej, co przejawia się w powściagliwości Brytyjczyków w kwestii wyrażania swych myśli, emocji, uczuć otwarcie, w odróżnieniu od zaskakującej bezpośredniości w kulturze amerykańskiej: Hester: Mr. Arbuthnot has a beautiful nature! He is so simple, so sincere. He has one of the most beautiful natures I have ever come cross. It is a privilege to meet him. Cechą charakterystyczną analizowanego aktu komunikacyjnego jest brak dystansu w omawianiu spraw prywatnych, co ma swoje odbicie w wyrażaniu uczuć kobiety do przedstawiciela płci przeciwnej ze strony interlokutora kultury amerykańskiej, w odróżnieniu od bezwzględnej powściągliwości Brytyjczyków.

W polskim środowisku kulturowo-językowym otwarty przejaw sympatii do płci przeciwnej nie jest czymś niezwykłym, jak w poniższym przykładzie:

(2) Lucja: Zapomina pan o Zoni.

Profesor Wilczur: Ach, o Zoni! Ta poczciwa kobieta zawsze darzyła mnie nadmiarem uczuć.

Lucja: Nietrudno to spostrzec. Sama nie wiem, która z nas ma więcej szans.

Powiedziała to z wyraźnq kokieteriq $i$ Wilczur odpowiedział zażenowany:

Profesor Wilczur: Żartuje pani.

Lucja: Wcale nie żartuję. Tak się pan broni przede mnq, jakbym byla jaką́ groźnq megierq. Przecież pan wie, jak bardzo pana kocham. Przecież pan wie.

Wzięła jego rękę i powiedziała:

Lucja: Nigdy pana nie porzuce. I nigdy się z panem nie rozstanę, Profesorze! Jest pan pierwszym czlowiekiem, którego usiluję uwieść. Niech się pan ulituje nad moim brakiem wprawy! (Tadeusz Dołęga-Mostowicz. Profesor Wilczur).

Zatem wyznanie młodej dziewczyny miłości mężczyźnie mieści się w granicach dobrego gustu $\mathrm{W}$ polskim środowisku językowym, co $\mathrm{z}$ kolei byłoby niespotykane w kulturze ukraińskiej, gdzie prawo wyznania miłości w relacjach męsko-damskich jest zarezerwowane wyłącznie dla osób płci męskiej. Podczas gdy w środowisku brytyjskim przeważa powściagliwość w kwestii wyrażania swych myśli, emocji, uczuć otwarcie ze strony obu płci. Fakt ten ma bezpośredni związek z purytańskim trybem życia Brytyjczyków. To właśnie purytanizm, w dużej mierze, wyznacza zasady zachowania w społeczeństwie brytyjskim. Jak słusznie podkreśla językoznawca Krystyna Pisarkowa: "przypisuje się Anglikowi niepojęty dla Polaka spokój (a. flegma): znaczenie wyrazu: 'człowiek zimny, obojętny, flegmatyczny, w; a także 'mizerny' (blady jak śmierć angielska), 'delikatność'. Współczesny stereotyp 
rozszerzono o kilka określeń precyzji „ułożenie”: wytworny, dystyngowany, elegancki, przystojny, wysoki bo sztywny, spokojny, opanowany, zimny, snob"s.

W ukraińskim środowisku językowym przeważają cechy otwartości, wylewności, szczerości, co określa kulturę ukraińską jako kulturę niskiego kontekstu, gdzie często w mowie potocznej spotyka się wyrażanie krytycznych uwag otwarcie, towarzyszące nie tylko rozmowie osób, które się znają; otwarta krytyka również obecna w interakcji osób mało znajomych, jak w następnej sytuacji:

(3) Олена: Чого ви говорите про речі, котрих добре не розумієте? Се ж вам не личить! Будьте таким, яким ви є, і не думайте йти другим під лад.

Фельс: Чому ви до мене такі гострі...? Завсігди маєте щось на мені критикувати, а мене се болить.

Олена: (відповіла м'яким, перепрошуючим голосом) Я не хочу, щоб над вами хто глумився...

Фельс: (цілуючи Олені руки) Ви мій ангел-хоронитель! (Ольга Кобилянська. Людина).

Taki otwarty przejaw uwag krytycznych jest nie do przyjęcia w innych środowiskach komunikacyjnych, między innymi, w polskim środowisku kulturowym, jak w poniższym przykładzie:

(4) „Połaniecki zaś pomyślat:

„Bytabyś pustelnica pod warunkiem, żeby na drugim brzegu jeziora stato pare tuzinów frantów i przypatrywało się przez lornetki, co pustelnica robi i jak wyglada".

Byt zbyt dobrze wychowanym, żeby powiedzieć jej wprost to, co pomyślat, ale powiedziat jej coś podobnego i co można było tak zrozumieć”(Henryk Sienkiewicz. Rodzina Połanieckich).

Komunikatywny optymizm interlokutora amerykańskiego przejawia się w komunikacyjnej reakcji na przywitanie: How are you? - Fine!, zgodnie z zasada amerykańskiego stylu życia: Keep smiling! Do not worry! Be happy!

Co ciekawe, to typowe angielskie przywitanie: How are you?!, wcale nie jest zachętą dla interlokutora, żeby nam zdradził szczegóły ze swojego życia, jest to zwrot tylko grzecznościowy, który pełni jedynie funkcję fatyczną. W polskim środowisku językowym na pytanie Jak się masz? Co slychać?! odpowiedz brzmi mniej optymistycznie: Jakoś leci! Nic nowego! Nic dobrego!, co odzwierciedla skłonność polskiego interlokutora do narzekania na wszystko i wszystkich. W ukraińskim środowisku językowym na pytanie $\boldsymbol{Я}_{\boldsymbol{\kappa}}$ справи? usłyszymy dość rozbudowaną opowieść o rzeczywistej sytuacji rozmówcy. Ponadto zarówno z ust Amerykanina jak i Brytyjczyka rzadziej padnie słowo źle, gdyż z natury są oni pozytywnie nastawieni do życia. W ukraińskich i polskich realiach tendencja jest wręcz odwrotna. Często pretekstem do rozmowy jest chęć ponarzekania na jakiś fragment rzeczywistości.

W tym zjawisku językowym kultur polskiej i ukraińskiej odzwierciedla się narodowy charakter kultury słowiańskiej, z wysoką ekspresywnością, wrażliwością, wylewnością i otwartością, która jednak nie ma miejsca w sytuacji doznania krzywdy, rozczarowania, $\mathrm{w}$ chwili obrażania się na interlokutora. W takich sytuacjach dość często stosowany jest bardzo specyficzny środek komunikacyjny — milczenie:

(5) „- Може, маєм що переказати для мами? - спитала Зоня. Сподіваюсь кожної хвилини Дори Вальде...

- Нічого не переказую і не поїду.

- А Дорі Вальде що переказати?

\footnotetext{
${ }^{5}$ Tamże, s. 66.
} 
— Від мене?... Альбінській? Ні, Альбінським я не маю що переказувати, нехай мене залишать у супокою. Я їх не хочу знати, я їх...

Дора стояла ще оперта плечима до стіни, і Юліян її застав у такій позиції.

- Ви чули, пані Вальде? - спитав ще схвильованим голосом.

- Чула, — відповіла шепотом.

- Вибачте, я був подразнений.

Мовчанка.

— Я відказував на Альбінських.

— Я зайшла сюди попрощатися..., але більше не зайду.

- I не вибачите мені?

Знову мовчанка!" (Ольга Кобилянська. Апостол черні).

$\mathrm{W}$ tym kontekście interpretacyjnym milczenie występuję $\mathrm{w}$ celu przejawu dezaprobaty z powodu czegoś nieprzyjemnego lub doznania krzywdy ze strony interlokutora. $\mathrm{W}$ podobnych sytuacjach dialog interpersonalny jest kontynuowany w sposób niewerbalny. Więc w takich przypadkach mamy do czynienie z milczeniem jak jedną z form illokucji pośrednich. W analizowanych kulturach amerykańskiej i brytyjskiej zdecydowanie cześciej jest stosowana inna forma pośredniego aktu komunikacyjnego - przemilczenie, w celu realizowania zasady taktu. Wymaga on użyć więcej wysiłku interpretacyjnego w celu prawidłowej interpretacji intencji autora przemilczenia. Nawet wtedy, jeśli rozumienie odniesie się jedynie do poszukiwań motywacji aktu przemilczenia, sukces aktu jest zapewniony, ponieważ właśnie intencja jest sednem każdego aktu komunikacyjnego, ją więc należy odkryć.

W kulturze ukraińskiej bardzo wyraźnie przejawia się zasada skromności, jak w poniższym przykładzie: “Тим часом щиие спасибі вам, українче Юліяне Цезаревичу.. Коли ви були раз лицарем для нас, то будьте ним і дальше...” (Ольга Кобилянська. Апостол черні).

Komunikacyjna reakcja Juliana i jego ojca polega na konsekwentnym zastosowaniu maksymy skromności:

„Максим Цезаревич: Ви переоиінюєте вчинок мого сина, отче. Це звичайна юнацька відвага.

Юліян Цезаревич: Найкраще, шановний отче, забути за мій незначний учинок якнайскоріше... Мені цілком не треба дякувати. Подайте руку і будемо поквитовані" (Ольга Кобилянська. Апостол черні).

W środowiskach kulturowych polskim, brytyjskim i amerykańskim bardziej grzecznościowym jest akceptacja pochwały, niż jej ciagłe odrzucanie. W przeciwnym razie, jak słusznie podkreśla brytyjski lingwista Geoffrey Leech, notoryczna nie akceptacja pochwały doprowadzić może do paradoksu uprzejmości na wzór sytuacji, kiedy to dwoje dżentelmenów spotkali się przy wejściu i nie mogą wejść, ponieważ grzeczność nie pozwala żadnemu z nich wejść pierwszym ${ }^{6}$. Właśnie dla tego w analizowanych środowiskach kulturowo-językowych bardziej uprzejmym jest akceptacja pochwały, wyrażając podziękowanie, niż jej nie akceptacja. W ten sposób w kulturach polskiej, brytyjskiej, amerykańskiej, realizowany jest kompromis w interakcji zasady skromności i zasady akceptacji.

Podsumowanie. Ten krótki przegląd różnic językowo-kulturowych uświadamia nam specyfikę międzykulturowej komunikacji interpersonalnej, jak również przyczynia się do możliwości badań na szeroką skale w zakresie porównywania strukturalnych, funkcjonalnych i pragmatycznych modeli aktów komunikacyjnych na materiale międzynarodowego dialogu interpersonalnego.

\footnotetext{
${ }^{6}$ G. L e e ch, Principles of Pragmatics, London 1983, P. 113.
} 